\section{Institute of Physics}

THE annual report of the Institute of Physics for the year 1937, which has just been published, shows that its membership continues to increase in a most satisfactory way. It was just over a thousand at the end of the year, and is now considered to be representative of British physicists both at home and overseas. The most important activity of the Institute during the year covered by the report was the Second Conference on Industrial Physics held in the University of Birmingham in March 1937, the subject being "Optical Devices in Research and Industry" (see Nature of April 3, 1937, p. 600). The various branches of the Institute in Great Britain held a number of meetings during the year and the committees of the overseas branches did valuable work in various ways. The report states that there was a further increase in the number of vacancies for physicists of which the Institute was notified, the figure being 197 for the year. Some vacancies for laboratory assistants were filled from among those holding the Institute's certificate in laboratory arts. The report states that the scope of the Journal of Scientific Instruments, which is produced by the Institute in co-operation with the National Physical Laboratory, has been enlarged to include items dealing with the applications of physics to industry.

\section{A Proposed Scientific Film Society}

A SCIEnTific Frim Group of the Association of Scientific Workers was formed about a year ago to encourage the growth of good instructional and documentary films, dealing both with 'pure science' and, perhaps even more important, with science as a social force. The Group has accordingly given shows of approved scientific films in London, Cambridge, Oxford and elsewhere, which have demonstrated that there is a considerable public for such films. To enable this work to continue on a more ample scale in London, however, while complying with L.C.C. regulations, it has now become necessary to consider forming a Scientific Film Society. Such a Society would be open to all interested persons, whether members of the Association of Scientific Workers or not, and would give at least four film shows a year in a London cinema on Sunday afternoons. It would not be possible to sell tickets for such shows to the general public, but a limited number of guest tickets would be available to members. Any profits arising from the Society's work would be devoted exclusively to non-commercial purposes such as the making and adapting of scientific films. Further particulars about the proposed Society can be obtained from the honorary secretary of the Scientific Films Committee, Association of Scientific Workers, Kelvin House, 28 Hogarth Road, London, S.W.7.

\section{Joint Committee on Materials and their Testing}

UNDER the above title, an interesting new form of collaboration between twenty-five of the major scientific societies and technical institutions of Great Britain has been effected : the Committee has now issued its first annual report, rendered to the councils of the collaborating institutions concerned. The principal objects of the Joint Committee are threefold : (1) to promote joint discussions on the wider aspects of the subjects of materials and their testing ; (2) to assist a co-operating institution or society in the presentation of a paper or group of papers dealing with a more detailed aspect of one of these subjects ; and (3) to undertake those duties with regard to international matters which properly devolve on the Joint Committee in accordance with its terms of reference. The main activity in the period reviewed by the report was the organization of a general discussion on "Notched Bar Testing" held in Manchester on October 29, 1937, in which this interesting subject was reviewed in relation to research and opinion at home and abroad. Four comprehensive papers were submitted and these papers, together with a record of the most informative discussion which resulted, are now available in pamphlet form, obtainable on application to the secretary of the Manchester Association of Engineers. The Committee is now organizing a second general discussion on various aspects of "Nondestructive Testing", which will centre around papers presented by selected experts in Germany, Holland, the United States and Great Britain, on the use of $\mathrm{X}$-ray, gamma-ray, magnetic, electrical, aeronautical and other more general methods : this discussion will take place in London in October or November of the present year. The pooling of the efforts of technical bodies in promoting discussions in the wide and most important fields of the materials of construction should go a long way towards satisfying a long-felt want, and the further activities of the Joint Committee will be followed with much interest in scientific and technical centres.

\section{Magnetic Recording in Broadcasting}

IN a paper read by A. E. Barrett and J. C. F. Tweed to the Institution of Electrical Engineers on December 1, some of the methods of recording saund, especially those in connexion with their applications to Empire broadcasting, were considered. In Great Britain, very little information has been published on the subject of magnetic recording on steel tape. Dr. Stille, a German engineer, was the first to use steel tape for recording, and he made notable advances in the necessary technique. The British Broadcasting Company. first tested the system in 1930 when the Empire broadcasting service was being inaugurated. Extracts from the home programmes were recorded and afterwards reproduced in the Empire transmission. The first important programme to be radiated to the Empire by this means was that on Christmas Day 1932. It included a speech by King George V. Early in 1933, Marconi's Wireless Telegraph Co., Ltd., designed a machine in which many of the mechanical difficulties experienced with earlier models were successfully overcome. It has been developed further by both the Company and the B.B.C. Magnetic recording in its simplest form can be carried out by passing a length of steel tape at constant velocity through an electromagnetic device, called a recording head, which produces variations in the magnetism of the tape. Reproduction is effected by passing the magnetized tape at the same velocity 